\title{
Ryszard Parzęcki
}

\section{Teoria miejsca i przestrzeni społeczno-zawodowej człowieka w obszarze zawodów i pracy ludzkiej}

\section{Wprowadzenie}

Dokonujące się zmiany stawiają nowe zadania przed młodym człowiekiem i edukacją. Podstawowym warunkiem rozwoju współczesnego człowieka jest myślenie w kategoriach przyszłości ${ }^{1}$. W okresie ciągle dokonujących się przemian społecznych pojawiają się nowe potrzeby i dążenia w zakresie edukacji młodzieży. Zmiany powinny podążać w kierunku przejścia od zmaterializowanej rzeczywistości do społeczeństwa humanistycznego od globalnej centralizacji do samorządowego. W ekonomii jest to droga do wolnego rynku a w polityce - od izolacji do europejskiej integracji ${ }^{2}$.

Szybkie przemiany systemowe stwarzają wyzwanie pod adresem edukacji. Ludziom są niezbędne kompetencje, szczególnie młodzieży w erze wolnego rynku, szybkich i głębokich zmian na rynku pracy, niewyobrażalnych do niedawna skoków w dostępie do informacji, zacierania różnic między dzieciństwem, młodością i dorosłością.

$\overline{1}$ H. Kwiatkowska, Edukacja nauczycieli. Konteksty - kategorie - praktyki, Instytut Badań Edukacyjnych, Warszawa 1997, s. 16.

2 J. Niemiec, Intencja miłości u podstaw przemian edukacyjnych, [w:] J. Dołęga (red.), Solidarni z nauczaniem Jana Pawła II, Wydawnictwo Wszechnicy Mazurskiej, Olecko 1999. 
Według koncepcji C. Rogersa, dotyczącej człowieka funkcjonującego w pełni, jednostka współczesna żyje w środowisku ciągle zmieniającym się. Rozumienie świata nie wystarcza, powstaje konieczność rozumienia jego zmienności. Celem kształcenia nowoczesnego jest wspieranie zmian. Według tegoż autora „wykształconym jest ten człowiek, który nauczył się, jak się uczyć, adaptować i zmieniać, który zdał sobie sprawę, że żadna wiedza nie jest pewna, że tylko proces poszukiwania wiedzy daje podstawy pewności”3.

Człowiek jako jednostka rozumna istnieje w sobie i dla siebie, jest niezależny i autonomiczny, jest podmiotem działania stanowiącego o sobie. Poprzez akty wyboru celów, sposobów i warunków działania w obszarze życia zawodowego wzbogaca się wewnętrznie, ciągle dążąc do coraz doskonalszego wymiaru własnej podmiotowości. Tym samym człowiek wybiera wartości. Proces wzbogacania swojej psychiki w zasadniczym stopniu jest procesem ciągłego wyboru wartości. Trwa on przez całe życie człowieka.

W sytuacji wieloaspektowego traktowania człowieka w kontekście jego przygotowania do życia zawodowego istnieje wiele problemów odczuwalnych przez coraz większe grupy ludzi, szczególnie dotkliwe jest poczucie zagubienia, a w związku $\mathrm{z}$ tym potrzeba pomocy w ich rozwiązywaniu. Rozważając swoje szanse i możliwości w sferze kształcenia i pracy zawodowej, czy też w wyborze orientacji życiowej, każdy współczesny człowiek jest „spowity jakby całunem zawodowej specjalizacji, która określa jego miejsce w strukturze społecznej, uwarunkowuje jego profesjonalne umiejscowienie, wytycza cele i zadania jego wysiłku zawodowego i osobowego, daje mu sens znajdywania się w układzie stosunków społeczno-ekonomicznych, politycznych i kulturowych"4.

\section{Ciągłość zawodowego rozwoju człowieka}

Rozwój zawod owy człowiekajest ściśle powiązany z różnymi kategoriami życia społecznego i stanowi jakby wypadkową rozwoju fizycznego, umysłowego, uczuciowego, erotycznego, społecznego, kulturowego

3 Cyt. za: K. Blusz, Edukacja a wyzwolenie, Oficyna Wydawnicza „Impuls”, Kraków 1992, s. 115.

$4 \quad$ J. Legowicz, Życie dla życia, Wiedza Powszechna, Warszawa 1984, s. 7. 
i moralnego. Rozważając teorie rozwoju zawodowego, niezwykle ważne jest określenie determinantów, które mają wpływ na podejmowanie przez człowieka decyzji życiowych dotyczących np. wyboru zawodu, szkoły, podjęcia pracy i innych. Wyjaśnienie wyborów oparte jest na rozwojowych teoriach zawodowego wyboru, które powszechnie przyjmowane są jako teoretyczna podstawa działań poradniczych. Kierunek ten zapoczątkowany przez Ch. Bühler, rozwinięty został do postaci spójnej teorii przez E. Ginzberga i D.E. Supera, wzbogaconej i pogłębionej przez wielu kontynuatorów rozwojowego ujęcia zawodowego wyboru, takich jak: J.W. Axelrad, J.P. Jordan, M.B. Heyde, D.V. Tiedeman.

W ostatnich latach XX wieku problematykę tę podjęli: K. Czarnecki, A. Bańka, T.W. Nowacki, Z. Wiatrowski, W. Rachalska, B. Wojtasik i inni ${ }^{5}$.

Rozwój zawodowy definiowany jest jako „związany z pracą proces indywidualnego wzrostu, zdobywania umiejętności w rozwoju”. ${ }^{\text {. Mó- }}$ wiąc o rozwoju trzeba myśleć o diagnozie zmian, jakie zaszły w kimś na przestrzeni pewnego czasu. Istotne jest też ustalenie, po czym poznajemy, że się rozwijamy w trakcie edukacji czy pracy zawodowej.

Teorie rozwojowe nie koncentrują się na pojęciu - wybór zawodu - uznając je za zbyt wąskie i oddające stan rzeczy zbyt stabilny, ograniczony do wąskiego fragmentu wydarzeń, pozbawiony ciągłości i perspektywy.

Rozwój zawodowy to proces, w którym występują wszelkie zmiany rozwojowe mające miejsce w różnych płaszczyznach funkcjonowania jednostki, które czynią ją zdolną do budowania własnej drogi zawodowej, umiejscawiania się w świecie pracy i stabilnego utrzymywania się w nim.

$5 \quad$ M.in. analizę tego zagadnienia znajdzie Czytelnik w pracy: K. Czarnecki, S. Karaś, Profesjologia w zarysie, Instytut Technologii Eksploatacji, Radom 1995; R. Parzęcki, K. Symela, B. Zawadzki, Orientacja i poradnictwo zawodowe, Instytut Technologii Eksploatacji, Radom 1995; R. Parzęcki, Podstawy wiedzy o edukacji i poradnictwie zawodowym, Wyższa Szkoła Humanistyczno-Ekonomiczna we Włocławku, Włocławek 1999; A. Bańka, Zawodoznawstwo. Poradnictwo zawodowe. Pośrednictwo pracy. Psychologiczne metody i strategie pomocy bezrobotnym, PRINT-B, Poznań 1995; W. Rachalska, Poradnictwo wobec problemów jednostki i rynku pracy, „Pedagogika Pracy" 2001, nr 38; B. Wojtasik (red.), Podejmowanie decyzji zawodowych przez młodzież $i$ osoby dorosłe $w$ nowej rzeczywistości społeczno-politycznej, Instytut Pedagogiki UWr-ITE, Wrocław - Radom 2001.

6 M. Waters, Słownik rozwoju osobistego. Pojęcia i teorie samodoskonalenia, Medium, Warszawa 1999, s. 198. 
Omawiając rozwój zawodowy człowieka należy zwrócić szczególną uwagę na jego stosunek do pracy, a także na czynniki kształtujące tenże rozwój oraz na przemiany zachodzące w trakcie tego rozwoju. Ideę rozwoju podjęło bardzo wielu badaczy zwracając szczególną uwagę na czas aktywności zawodowej z uwzględnieniem okresu stabilizacji oraz spoczynku. Największe zainteresowanie wzbudziła w Polsce teoria D.E. Supera? W Wwojej teorii przyznał centralne miejsce roli, jaką spełnia świadomość, stwierdzając, iż rozwój zawodowy jest procesem, w którym samoświadomość jednostki podlega rozwojowi samorealizacji. Samoświadomość realizuje się poprzez wybór i poszukiwanie takiego zajęcia, które umożliwia realizację zdolności oraz zainteresowań człowieka. Donald Edwin Super stwierdza, iż elementy procesu rozwoju zawodowego występują na przestrzeni całego życia. Dzieli ten okres na pięć etapów: rozwój, poszukiwanie, utrwalanie, kontynuacja oraz schyłek. Każdy etap jest powiązany z kategorią wieku. Centrum rozwoju zawodowego stanowi obraz własnej osoby, pozostającej w nieustannych relacjach z otoczeniem.

Teoria ciągłości rozwojowej D.E. Supera powstała jako wynik pogłębionych badań empirycznych i analiz teoretycznych. Autor sformułował teoretyczne założenia rozwoju zawodowego w postaci 12 twierdzeń. Ze względu na ograniczony zakres niniejszego artykułu podaję je w skróconej postaci:

1) rozwój zawodowy jest postępującym, ciągłym i zwykle nieodwracalnym procesem obejmującym stadia: rośnięcia, eksploracji, stabilizacji, zachowania status quo i schyłkowe;

2) rozwój zawodowy jest wzorcowym i przewidywalnym procesem ze względu na jednostkę, od której we współczesnej kulturze oczekuje się wykonania serii zadań, przystosowanych do etapu jej rozwoju;

3) rozwój zawodowy jest procesem dynamicznym, bowiem pociąga za sobą konieczność kompromisu między czynnikami osobowościowymi a społecznymi;

4) pojęcie „ja” zaczyna się krystalizować w okresie dojrzewania i wówczas może być ono określone w terminach zawodowych;

$\overline{7}$ J. Kurjaniuk, Teoria rozwoju zawodowego a systemy klasyfikacyjne zawodów, [w:] E. Laska (red.), Pedagogika pracy, problematyka i przeglad badań, WSiP, Warszawa 1982, s. 306-307. 
5) czynniki obiektywne odgrywają z wiekiem coraz większą rolę w rozwoju zawodowym jednostki;

6) rozwój poprzez stadia życiowe jest czynnikiem współdziałania różnych wpływów. W kolejnych stadiach życia jednostka stoi przed koniecznością uporania się z nowymi i coraz bardziej złożonymi etapami społecznych dążeń;

7) tempo przechodzenia jednostki do każdego kolejnego poziomu rozwoju zawodowego jest uzależnione od pozycji społecznej i ekonomicznej jej rodziców, potrzeb własnych oraz aktualnych warunków ekonomicznych kraju;

8) dziedzina zawodowa, którą jednostka wybiera zależy od jej zainteresowań i potrzeb oraz od poziomu wykształcenia, a także od struktury zawodowej oraz zdolności jednostki;

9) jednym z podstawowych założeń torii rozwoju zawodowego jest teza o zawodowej multipotencjalności jednostki;

10) satysfakcja życiowa i zawodowa zależą od zakresu, w jakim jednostka może w swojej pracy dać wyraz własnym zdolnościom, zainteresowaniom, wartościom i cechom osobowości;

11) stopień satysfakcji wynikającej z pracy jednostki jest proporcjonalny do stopnia, w jakim zdoła ona dostosować do tej pracy swoje pojęcie „ja”;

12) praca i zawód stanowią główny czynnik kształtowania się osobowości człowieka i dla większości ludzi są centrum ich zainteresowań ${ }^{8}$.

Interesującą koncepcję okresów rozwojowych przedstawił też E.H. Schein. Według niego jednostki muszą pokonywać etapy w trzech płaszczyznach: biospołecznej, rodzinnej oraz zawodowej. Na każdym etapie człowiek jest konfrontowany z różnymi sytuacjami wyboru oraz przeszkodami. Przywołane koncepcje rozwojowe te i inne związane z poszczególnymi etapami różnią się co do ilości, aspektów społecznych, psychologicznych oraz zawodowych ${ }^{9}$.

8 Por. M. Czerwińska-Jasiewicz, Psychologiczna analiza cech decyzji zawodowych młodzieży, Wydawnictwo Uniwersytetu Warszawskiego, Warszawa 1979, s. 21-23.

$9 \quad$ Szerzej analizę koncepcji rozwojowych przedstawiam w pracy: R. Parzęcki, Plany edukacyjno-zawodowe młodzieży w stadium eksploracji. Zamierzenia - Wybory - Realia, Wydawnictwo Uniwersytetu Mikołaja Kopernika, Toruń 2004, s. 119-125; także: R. Parzęcki, Wieloaspektowość i złożoność poradnictwa zawodowego czyli action research, [w:] R. Parzęcki (red.) Poradnictwo zawodowe w teorii i praktyce, Gdańska Wyższa Szkoła Humanistyczna, Gdańsk 2010, s. 9-13. 
Jednak największy wpływ na ożywienie i ukazanie nowych możliwości koncepcji rozwojowych wywołał D.E. Super. Twierdził on, że relacja: człowiek-praca zawodowa jest relacją całożyciową, choć w różnych okresach ma ona inną postać i zajmuje inną pozycją w planach życiowych.

W związku z tym człowiek podejmuje wielokrotnie w życiu poważne decyzje zawodowe (wybór zawodu, szkoły, miejsca pracy, szukanie pracy, przekwalifikowanie, kierunek doskonalenia zawodowego i inne).

W Polsce rozwojowe traktowanie procesów zachodzących między człowiekiem i pracą zostało umożliwione przez powstanie pedagogiki pracy. Między innymi autorem prac nad rozwojem zawodowym jest Z. Wiatrowski, który dla kolejnych etapów życia człowieka przyjął okres kształcenia przedzawodowego, zawodowego, doskonalenia zawodowego i aktywności zawodowej ${ }^{10}$. Tenże i inni poddając analizie okres trzeci formułują i analizują linię rozwoju zawodowego pracownika, którą tworzy: przygotowanie zawodowe, adaptacja społeczno-zawodowa, identyfikacja i stabilizacja zawodowa, sukces zawodowy oraz mistrzostwo w zawodzie ${ }^{11}$.

Należy też podkreślić, że termin rozwój zawodowy jest określany jako społecznie pożądany i ukierunkowany proces przemian ilościowych i jakościowych człowieka, warunkujących jego świadomy, celowy, aktywny i odpowiedzialny udział w kształtowaniu samego siebie i przez to bliższego oraz dalszego otoczenia. Ponadto termin „rozwój” i pochodna jest bardzo starannie zdefiniowany i opisany w różnych jego ujęciach: biologicznym, fizycznym, psychicznym, społecznym, kulturowym. To proces całożyciowych przemian ilościowych, przebiegających w różnych warunkach, formach zachowania się i działania człowieka $^{12}$.

10 Z. Wiatrowski, Podstawy pedagogiki pracy, Wydawnictwo Akademii Bydgoskiej im. Kazimierza Wielkiego, Bydgoszcz 2005, s. 31-38.

11 M.in. J.E. Karney, Psychopedagogika pracy, Wydawnictwo Akademickie Żak, Warszawa 2007, s. 38-56; J. Wilsz, Teoria pracy, Oficyna Wydawnicza „Impuls”, Kraków 2009, s. 235-328.

12 K.M. Czarnecki, P. Kowolik., Profesjologia, [w:] Encyklopedia pedagogiczna XXI wieku, t. 2, Wydawnictwo Akademickie Żak, Warszawa 2005, s. 935-940; także: K.M. Czarnecki, Profesjologia. Nauka o zawodowym rozwoju człowieka, Oficyna Wydawnicza „Humanitas”, Sosnowiec 2010, s. 29-60. 


\section{Miejsca i przestrzeń społeczno-zawodowa jako wyznaczniki rozwoju i działania człowieka}

Podstawowymi terminami zawartymi w tej części tekstu są: miejsce i przestrzeń. Termin - miejsce - to wolna przestrzeń, pomieszczenie, które można zająć, gdzie można coś zmieścić, umieścić. Miejsca było dość dla wszystkich. To także określona część, wycinek przestrzeni np. ziemi, przedmiotu, ciała. Miejsca ciche, niedostępne, ustronne, pobytu, pracy, zatrudnienia, katastrofy. Być na miejscu, swoim, właściwym, odpowiednim, usprawiedliwionym. To również teren zamieszkały przez ludzi: miejscowość, miejsce rodzinne, zamieszkania, a także ograniczony wycinek przestrzeni w jakimś pomieszczeniu ${ }^{13}$.

Termin - miejsce - ma bardzo szeroki zakres treściowy i definiowany jest jako:

- wolna przestrzeń, którą można zająć i wypełnić;

- część określonej przestrzeni, z którą coś się dzieje lub działo;

- miejsce pracy człowieka, zatrudnienia, zakład, stanowisko pracownicze;

- prawidłowy lub nieprawidłowy układ przedmiotów, ludzi wobec siebie, swoich zadań, działań, odpowiedzialności;

- zmienność miejsca pobytu i pracy;

- ograniczony wycinek przestrzeni np. przy kierownicy, biurku;

- pozycja jednostki w grupie, zespole pracowniczym;

- proces ubiegania się o zajęcie określonego miejsca w życiu społecznym ludzi.

Jest jeszcze kilka innych rozróżnień rozumienia terminu - miejsce - lecz nie wiążą się one z człowiekiem, jego życiem, rozwojem i działaniem. Podane definicje wiążą się w większym lub mniejszym stopniu z życiem, rozwojem i działaniem człowieka, a szczególnie ujęcia akcentujące „wolną przestrzeń”, którą można zająć i wypełnić.

Kolejny termin - przestrzeń - odnosi się nie tylko do otoczenia geograficzno-biologicznego, ale głównie do „przestrzeni społecznej”, ludzkiej, człowieczej, tj. miejsca człowieka w społecznych układach grup. Nie ulega wątpliwości, że określenia: wolna przestrzeń, miejsce pracy zawodowej, układ ludzi i przedmiotów, ludzi wobec zadań,

13 S. Skorupka, H. Auderska, Z. Łempicka (red.), Mały słownik języka polskiego, PWN, Warszawa 1969, s. 386-387. 
pozycja jednostki w grupie, proces ubiegania się o zajęcie miejsca w życiu społecznym i zawodowym, dobrze ilustrują - miejsce i przestrzeń człowieka w społecznych układach stosunków, zachowań i zadań. Miejsce i przestrzeń społeczno-zawodowa są nieodłącznymi elementami i wyznacznikami rozwoju, życia i działania człowieka, są z nim „na stałe”, przez całe jego życie, od początku aż do zgonu, przykładowo:

- poczęte dziecko zajmuje miejsce i przestrzeń w łonie matki;

- niemowlę zajmuje swoje miejsce i przestrzeń w domu rodzinnym, żłobku;

- dziecko w wieku przedszkolnym zajmuje miejsce i przestrzeń w sali zabaw, przy stoliku, na leżaku;

- uczeń szkoły podstawowej, liceum, szkoły zawodowej zajmuje odpowiednie miejsce w klasie, w ławce..., warsztacie...;

- absolwenci szkół zawodowych... odpowiednio w zakładach pracy;

- emeryci i renciści... w domu rodzinnym, starców, miejscach pracy chronionej.

Człowiek stopniowo wraz $\mathrm{z}$ rozwojem fizycznym i społecznym zajmuje zmieniające się miejsca i przestrzenie. Można mówić o przestrzeni: zabawowej dzieci, szkolnej, uczelnianej, pracowniczej, wypoczynkowej, emerytów. Życie i rozwój jednostki ludzkiej są związane z miejscem i przestrzenią społeczno-zawodową ${ }^{14}$.

Definicja „miejsca” jako „wycinka przestrzeni” oznacza to miejsce i tę przestrzeń, które zajmuje człowiek w procesie kształtowania swojego rozwoju. Z kolei określenie terminu - miejsce - jako „procesu prowadzącego do zajęcia określonej pozycji w życiu społecznym, oznacza miejsce, jakie zajmuje jednostka w grupie pracowniczej (robotnik, technik, inżynier, mistrz, kierownik, dyrektor $)^{15}$. Przykłady definicji terminów: „miejsce” i „przestrzeń” człowieka wskazujący na fakt, że zajmuje on zawsze określone, często „wywalczone” miejsca i przestrzeń fizyczną, a wraz z nią miejsce i przestrzeń społeczno-zawodową.

14 Szerzej na ten temat pisze K.M. Czarnecki, Profesjologia. Nauka o zawodowym..., s. 63-66.

15 Ibidem, s. 67, ponadto należy zwrócić uwagę, że termin „przestrzeń” jest pojęciem bardzo obszernym, zróżnicowanym i występuje jako: 1) jedno z podstawowych cech materii (filozofia); 2) trójwymiarowa nieograniczona rozciągłość lub jej część (fizyka); 3) zbiór dowolnych obiektów, wektorów, figur (matematyka). Za: Nowa encyklopedia powszechna PWN, t. 5, Wydawnictwo Naukowe PWN, Warszawa 1998, s. 373. 


\section{Twierdzenia teorii miejsca i przestrzeni społeczno-zawodowej człowieka}

Twierdzenie to tyle, co zdanie orzekające coś o przedmiocie, którego dotyczy. Zdania można klasyfikować ze względu na różne zasady podziału. Można np. dzielić je na twierdzenia empiryczne i analityczne. W pierwszych z nich twierdzi się coś o rzeczywistości dostępnej, bezpośredniej bądź pośredniej obserwacji. Twierdzenia takie bywają też nazywane zdaniami syntetycznymi. Zdania te są prawdziwe wtedy, kiedy rzeczy, zjawiska, zdarzenia, procesy lub regularności ich istnienia czy pojawiania się są rzeczywiście takie, jak one głoszą. Ponadto twierdzenia te są charakterystyczne dla nauk empirycznych - zarówno przyrodniczych, jak humanistycznych czy społecznych ${ }^{16}$.

Kolejne pojęcie - teoria, to usystematyzowany zbiór idei bądź wiadomości. Pojęcie to może oznaczać wyjaśnianie określonego zjawiska (np. spadania ciał) albo naukowy system wyjaśniający naturę materii (np. teoria atomistyczna) czy tłumaczący wszystkie zjawiska zachodzące we wszechświecie lub też jest to po prostu zbiór poglądów mających na celu uwarunkowanie naszego działania. Teorię poznania nazywa się wszelką refleksją krytyczną dotyczącą istoty i ograniczeń naszego umysłu ${ }^{17}$.

Przedstawiam główne twierdzenia teorii miejsca i przestrzeni społeczno-zawodowej człowieka, a także teorii zawodowego rozwoju. Są one ściśle ze sobą powiązane, wzajemnie się dopełniają, dając obraz teoretycznych podstaw rozwoju człowieka w ciągu całego życia.

Oto twierdzenia:

1) zawód człowieka jest zespołem czynności wyuczonych i wyspecjalizowanych, wyznacza miejsce jednostki w podziale pracy;

2) człowiek niezależnie od wieku, środowiska i sytuacji zajmuje przez swoje życie, określone miejsca i przestrzenie społeczno-zawodowe w podziale ról, zadań, pracy, zawodów, stanowisk, funkcji;

3) miejsca i przestrzenie społeczno-zawodowe zmieniają się wraz $\mathrm{z}$ rozwojem człowieka;

16 Szerzej: S. Nowak, Metodologia badań społecznych, Wydawnictwo Naukowe PWN, Warszawa 2006, s. 197 i nast.

17 J. Didier, Słownik filozofii, Wydawnictwo Książnica, Warszawa 1992, s. 347. 
4) zmiany miejsca i przestrzeni społeczno-zawodowych zależne są od czynników: podmiotowych i przedmiotowych jednostki ludzkiej oraz istniejących warunków społeczno-gospodarczych, kulturowych danego kraju.

5) określone miejsca i przestrzenie społeczno-zawodowe jednostka ludzka zajmuje głównie dzięki własnej aktywności prozawodowej i zawodowej;

6) szczególne znaczenie w zawodowym rozwoju jednostki mają miejsca i przestrzenie społeczno-zawodowe w systemie edukacji (poziom osiągnięć szkolnych, zainteresowania, motywacja uczenia się); w zakładzie pracy (satysfakcja z pracy) oraz samodoskonalenie zawodowe i osobowościowe;

7) psychiczne właściwości jednostki stanowią wyznacznik zawodowego rozwoju w konkretnych prozawodowych i zawodowych miejscach, czasie, warunkach i sytuacjach;

8) w kolejno zajmowanych miejscach i przestrzeniach społeczno-zawodowych jednostka kształtuje osobowość prozawodową i zawodową, a szczególnie takie składniki jak:

- nastawienia i wyobrażenia prozawodowe;

- wiedza i czynności prozawodowe i zawodowe;

- motywacja podejmowania nauki i pracy zawodowej;

- motywacja racjonalizacji pracy zawodowej;

9) miejsca i przestrzenie społeczno-zawodowe (czas pobytu w szkole i pracy zawodowej oraz przejścia na emeryturę) są względnie stałe;

10) w określonych miejscach i przestrzeniach społeczno-zawodowych oraz w czasie i sytuacjach jednostka realizuje swoje aspiracje prozawodowe i zawodowe;

11) realizacja Ja odbywa się zawsze w konkretnych miejscach i przestrzeniach społeczno-zawodowych (kraju, regionie, środowisku społeczno-zawodowym i kulturowym, szkole, zakładzie pracy);

12) jednostka rozwija się prozawodowo i zawodowo m.in. poprzez:

- motywację i trafną decyzję wyboru zawodu i szkoły;

- osiągane sukcesy szkolno-zawodowe;

- adaptację społeczno-zawodową w miejscu pracy;

- stabilizację społeczno-zawodową w zawodzie i miejscu pracy;

- aktywne życie prozawodowe; 
13) względnie stałe miejsca i przestrzenie społeczno-zawodowe stwarzają jednostce poczucie bezpieczeństwa społecznego, ekonomicznego;

14) poczucie własnej wartości zostaje zaburzone w przypadku utraty stabilności w pracy zawodowej dorosłych;

15) określone miejsca i przestrzenie społeczno-zawodowe są podstawowym wyznacznikiem wizji zawodowego rozwoju jednostki i jej życia;

16) w sytuacji rozbieżności cech miejsca i przestrzeni społeczno-zawodowej z oczekiwaniami, dążeniami i aspiracjami jednostki następuje wymuszona zmiana miejsca i przestrzeni na inną np. zmiana miejsca pracy;

17) miejsca i przestrzenie społeczno-zawodowe mogą się zmieniać nie tylko ze względu na rozbieżność cech jednostki, jej oczekiwań, dążeń, aspiracji, ale również ze wzglądu na postęp naukowo-techniczny;

18) jednostka o korzystniejszych predyspozycjach psychofizycznych zmienia się szybciej nie tylko sama, ale również jej otoczenie społeczno-zawodowe i kulturowe.

Zmiany, jakie zachodzą w świadomości i zachowaniu się prozawodowym i zawodowym człowieka, pojawiają się głównie dzięki miejscom i przestrzeniom społeczno-zawodowym wskutek aktywności jednostki ludzkiej.

Miejsca i przestrzenie społeczno-zawodowe każdej jednostki ludzkiej są nieodłącznym składnikiem jej życia, rozwoju, działania jak również powodzeń lub niepowodzeń zawodowych lub życiowych.

\section{Konkluzja}

Przedstawiony zakres treści oraz twierdzeń odnosi się do każdego człowieka we wszystkich etapach jego rozwoju zawodowego, zarówno wybierających zawody, jak również uczących się w różnych typach szkół tj. zasadniczych, średnich, wyższych czy dla dorosłych pracujących w różnych zakładach pracy. Przyjmuję, że bez określonych miejsc i przestrzeni społeczno-zawodowych, w jakich żyje, rozwija się i działa człowiek, jego rozwój ogólny, a szczególnie zawodowy jest niemożliwy. Przedstawiona teoria miejsca i przestrzeni społeczno-zawodowej rozwoju człowieka jest teorią interdyscyplinarną w stosunku do 
psychologii, pedagogiki i socjologii. Jest to teoria podstawowa w nauce o zawodowym rozwoju człowieka.

\begin{abstract}
In the article I present statements which are the result of many analyses, reflections, literature research, own empirical research, and reflections related to the individual professional development of children, adolescents, and adults. The text contains basic statements about the socio-occupational theory of place and space in the division of professions and in human labour. Social and professional „place and space” are inseparable elements and determinants of human development, life and activity, are related to people permanently, throughout their life, from conception to death.
\end{abstract}

\title{
Bibliografia
}

Bańka A., Zawodoznawstwo. Poradnictwo zawodowe. Pośrednictwo pracy. Psychologiczne metody i strategie pomocy bezrobotnym, PRINT-B, Poznań 1995.

Blusz K., Edukacja a wyzwolenie, Oficyna Wydawnicza „Impuls”, Kraków 1992.

Czarnecki K., Karaś S., Profesjologia w zarysie, Instytut Technologii Eksploatacji, Radom 1995.

Czarnecki K.M., Kowolik P., Profesjologia, [w:] Encyklopedia pedagogiczna XXI wieku, t. 2, Wydawnictwo Akademickie Żak, Warszawa 2005.

Czarnecki K.M., Profesjologia. Nauka o zawodowym rozwoju człowieka, Oficyna Wydawnicza „Humanitas”, Sosnowiec 2010.

Czerwińska-Jasiewicz M., Psychologiczna analiza cech decyzji zawodowych młodzieży, Wydawnictwo Uniwersytetu Warszawskiego, Warszawa 1979.

Didier J., Słownik filozofii, Wydawnictwo Książnica, Warszawa 1992.

Karney J.E., Psychopedagogika pracy, Wydawnictwo Akademickie Żak, Warszawa 2007.

Kurjaniuk J., Teoria rozwoju zawodowego a systemy klasyfikacyjne zawodów, [w:] E. Laska (red.), Pedagogika pracy, problematyka i przeglad badań, WSiP, Warszawa 1982.

Kwiatkowska H., Edukacja nauczycieli. Konteksty - kategorie - praktyki, Instytut Badań Edukacyjnych, Warszawa 1997.

Legowicz J., Życie dla życia, Wiedza Powszechna, Warszawa 1984. 
Niemiec J., Intencja miłości u podstaw przemian edukacyjnych, [w:] J. Dołęga (red.), Solidarni z nauczaniem Jana Pawła II, Wydawnictwo Wszechnicy Mazurskiej, Olecko 1999.

Nowa encyklopedia powszechna PWN, t. 5, Wydawnictwo Naukowe PWN, Warszawa 1998.

Nowak S., Metodologia badań społecznych, Wydawnictwo Naukowe PWN, Warszawa 2006.

Parzęcki R., Plany edukacyjno-zawodowe młodzieży w stadium eksploracji. Zamierzenia - Wybory - Realia, Wydawnictwo Uniwersytetu Mikołaja Kopernika, Toruń 2004.

Parzęcki R., Podstawy wiedzy o edukacji i poradnictwie zawodowym, Wyższa Szkoła Humanistyczno-Ekonomiczna we Włocławku, Włocławek 1999.

Parzęcki R., Symela K., Zawadzki B., Orientacja i poradnictwo zawodowe, Instytut Technologii Eksploatacji, Radom 1995.

Parzęcki R., Wieloaspektowość i złożoność poradnictwa zawodowego czyli action research, [w:] R. Parzęcki (red.) Poradnictwo zawodowe w teorii i praktyce, Gdańska Wyższa Szkoła Humanistyczna, Gdańsk 2010.

Rachalska W., Poradnictwo wobec problemów jednostki i rynku pracy, „Pedagogika Pracy” 2001, nr 38.

Skorupka S., Auderska H., Łempicka Z. (red.), Mały słownik języka polskiego, PWN, Warszawa 1969.

Waters M., Słownik rozwoju osobistego. Pojęcia i teorie samodoskonalenia, Medium, Warszawa 1999.

Wiatrowski Z., Podstawy pedagogiki pracy, Wydawnictwo Akademii Bydgoskiej im. Kazimierza Wielkiego, Bydgoszcz 2005.

Wilsz J., Teoria pracy, Oficyna Wydawnicza „Impuls”, Kraków 2009.

Wojtasik B. (red.), Podejmowanie decyzji zawodowych przez młodzież i osoby dorosłe w nowej rzeczywistości społeczno - politycznej, Instytut Pedagogiki UWr-ITE, Wrocław - Radom 2001. 